\title{
The Design Report Rubric: Measuring and Tracking Growth through Success
}

\author{
Robert Knecht, Barbara Moskal, and Michael Pavelich \\ Colorado School of Mines
}

\section{Introduction}

As an engineering institution, the Accreditation Board for Engineering and Technology (ABET) has had a powerful influence upon the program development process at the Colorado School of Mines (CSM) ${ }^{1}$. Accreditation is one piece of evidence that suggests the quality of CSM's engineering programs. All of CSM's undergraduate engineering programs are ABET accredited. Current ABET accreditation requirements reflect a philosophical shift that is consistent with the broader education community ${ }^{2}$. In the past, the demonstration of a quality program was examined through in-direct measures, such as faculty qualifications and student placement information that are related to student learning. Current requirements place an emphasis upon the direct demonstration that the program has an impact upon what students know and can do. Although indirect measures continue to be a portion of the evidential base, they are now considered to be only a small piece of a broader requirement.

ABET's shift in assessment emphasis is consistent with recent developments in the field of engineering education ${ }^{3}$. Curriculum reform in engineering education is underway that stresses the importance of teamwork, an awareness of both society's social and economic concerns, and an ability to adapt to the changing demands of the next century ${ }^{4,5,6}$. Many schools have adapted their curriculum to include engineering design courses that focus upon the development of these important skills and that include industrial partners in the curriculum design effort ${ }^{7,8,9}$.

Examination of the literature concerning engineering design provides diverse views of what engineering design is. For example, the Engineer's Council for Professional Development has described design in terms of the processes that are required to optimally "meet a stated objective" whereas Douglas ${ }^{10}$ has described design as a creative activity that converts ideas into "processes for producing new materials." Pahl and Beitz ${ }^{11}$ consider the integration of technical, psychological, systematic, and organizational aspects of engineering design as "prerequisites for the physical realization of solution ideas." Still others have argued that design includes teamwork and management skills ${ }^{12,13}$. Based on these different views of engineering design, Bieniawski ${ }^{14}$ has argued that design is not typically learned in a classroom setting, but rather through practice. CSM has responded to this concern in the development of the design stem. The design stem consists of four courses: freshman EPICS (Engineering Practices Introductory Course Sequence), sophomore EPICS, Field Session (junior year) and Senior Capstone design. An important component of each of these courses is the contribution of industrial partners who provide teams with authentic engineering projects 


\section{Purpose}

The purpose of this paper is to describe one of the assessment techniques that are being used in the evaluation of the Design (EPICS) program at CSM. EPICS comprises the first two required courses of the design stem. This article describes the process that was used to develop a scoring rubric for the evaluation of the students' final reports and the results of piloting the effectiveness of that rubric on the evaluation of the sophomore EPICS course. Brookhart ${ }^{15}$ has described scoring rubrics as "descriptive rating scales" that are useful in the evaluation of students' performances that evolve over an extended period. Over the course of a semester, EPICS students work in teams to solve problems and develop final reports based on these efforts. Since the final reports are a result of students' efforts over an extended period, scoring rubrics are an appropriate methodology for evaluating the outcome of the students' performances.

\section{Course Design}

Throughout the 15-week courses, Engineering students work in teams of four to six to solve problems that are solicited from industry and local businesses. Often the projects are humane or altruistic in nature, such as designing playground equipment for children with disabilities, or finding new and ingenious designs for solar ovens for African communities. Dealing directly with their clients, second-year students don't just simulate, but actually take on the professional roles necessary to implement the design process.

Projects, which are presented to students by industrial partners, reflect the student's technical maturity. All students in freshman EPICS work on the same project, which focuses on conceptual design and application of visualization (graphical) skills. Second-year students are given a choice from 4 categories of projects covering 12 disciplines, categorized in Figure 1.

\section{Design (EPICS) II Project Distribution}

\begin{tabular}{|c|c|c|c|}
\hline $\begin{array}{c}\text { Earth Engineering } \\
\text { Projects }\end{array}$ & $\begin{array}{c}\text { Process Engineering } \\
\text { Projects }\end{array}$ & $\begin{array}{c}\text { Product Engineering } \\
\text { Projects }\end{array}$ & $\begin{array}{c}\text { Science \& Business } \\
\text { Projects }\end{array}$ \\
\hline $\begin{array}{c}\text { Geology and Geological } \\
\text { Engineering }\end{array}$ & \begin{tabular}{|c} 
Chemical Engineering \& \\
Petroleum Refining
\end{tabular} & Engineering & $\begin{array}{l}\text { Chemistry \& } \\
\text { Geochemistry }\end{array}$ \\
\hline Geophysics & $\begin{array}{c}\text { Environmental Science } \\
\text { \& Engineering }\end{array}$ & & $\begin{array}{l}\text { Economics and } \\
\text { Business }\end{array}$ \\
\hline $\begin{array}{c}\text { Mining } \\
\text { Engineering }\end{array}$ & $\begin{array}{c}\text { Metallurgical and } \\
\text { Materials Engineering }\end{array}$ & & $\begin{array}{l}\text { Mathematical and } \\
\text { Computer Sciences }\end{array}$ \\
\hline $\begin{array}{l}\text { Petroleum } \\
\text { Engineering }\end{array}$ & & & Physics \\
\hline
\end{tabular}

Figure 1. Project Categories and Distribution of Disciplines for Design (EPICS) II

The primary focus for these projects is data acquisition and processing. Student teams have achieved national attention (NBC featured our playground equipment for children with disabilities) and national awards for excellence in design (such as, ASEE competition winners several years in a row). 
Mentored by multi-disciplinary faculty, students experience supervision, management, coaching and consulting as they take on the challenge of finding solutions to open-ended problems. EPICS faculty members are paired with other faculty members so that each pair consists of a technical expert (e.g., scientists or engineers) and a communications expert (e.g., English and communications instructors). Each EPICS mentor directs four to five teams (20 to 25 students) and serves the teams as a technical, communication, and teamwork consultant. Although each faculty member within a pairing assists different student teams, the existence of the pairings provides each instructor with a resource concerning the portion of the course that extends beyond his/her own expertise. In sophomore EPICS, the instructional team may or may not include a communications expert depending on the availability of staff. Both EPICS courses conclude with the students submitting a written report that describes and supports the team solution to the respective problem.

\section{Rubric Development}

In order to evaluate the quality of the students' final written reports, a scoring rubric (i.e., scoring method) was developed. The original rubric was designed by Leydens and Thompson ${ }^{16}$ to be consistent with the goals and objectives of the EPICS program. The specific student outcomes that the rubric was designed to assess are:

1. The team's proficiency in understanding the requirements of an external client.

2. The team's proficiency in designing and justifying a feasible solution for a project.

3. The team's proficiency in applying fundamental numerical analysis techniques that model a technical system or product.

4. The team's proficiency to communicate in writing the technical and economical feasibility of an engineering strategy.

The analytic scoring rubric was designed to evaluate both technical content (objectives 1, 2 and 3 ) and the effectiveness of the written communication (objective 4) apparent in the final report. The content portion of this rubric, which is shown in Table I, was reviewed and revised through the collaborative efforts of engineers and an assessment specialist and covers the areas of "audience", "purpose" and "evidence". The category of "audience" is designed to address objective 1: Whether the team identifies who the client is and what the client's needs are. This is considered an initial and essential step in industry when working with an external client. The second category, "purpose", examines the extent to which the teams develop and justify a feasible solution to the given problem (i.e., objective 2). The "evidence" category addresses the empirical evidence (i.e., objective 3 ) that is used to justify the final answer.

The communication portion of this rubric, which is shown in Table II, was developed through the combined efforts of an English and Communications experts and was reviewed by an assessment specialist. This portion emphasizes focus and coherence and assesses objective 4 . "Focus" refers to the organization of the document; "Coherence" emphasizes the details of written communication (e.g., sentence structure, grammar and spelling).

The scoring rubric was designed to assess a student's progress from their freshman year to graduation. Currently, the rubric is only being used to assess the students' performances in the EPICS courses; however, there are plans to use the rubric for the evaluation of juniors and 
Table I. Content Portion of Scoring Rubric Used to Score Final Reports from EPICS' Teams

\begin{tabular}{|c|c|c|c|c|}
\hline & $-0-$ & $\begin{array}{c}-1- \\
\text { Needs Improvement } \\
\text { "Data Dump" }\end{array}$ & "Partial Synthesis", & $\begin{array}{l}-3- \\
\text { Meets Expectations for a first } \\
\text { Draft of a Professional Report } \\
\text { "Synthesis of the Information" }\end{array}$ \\
\hline $\begin{array}{l}\text { Audience } \\
\text { (CLIENT) } \\
\text { Who is the client and } \\
\text { what are their needs? }\end{array}$ & $\begin{array}{l}\text { - Does not identify client } \\
\text { OR } \\
-\quad \text { Clients' needs. }\end{array}$ & $\begin{array}{l}\text { - Specifies who the client is } \\
\text { OR } \\
\text { - Specifies what the client's } \\
\text { needs are. }\end{array}$ & $\begin{array}{l}\text { Specifies who the client is, } \\
\text { what the client's needs are, } \\
\text { BUT } \\
\text { - Addresses only a subset of } \\
\text { the client's needs. }\end{array}$ & $\begin{array}{l}\text { Specifies who the client is, } \\
\text { what the clients' needs are, } \\
\text { AND } \\
\text { - Clearly addresses all the } \\
\text { clients' needs. }\end{array}$ \\
\hline $\begin{array}{l}\text { Purpose } \\
\text { (CONCLUSION) } \\
\text { What is the problem and } \\
\text { how can it be solved? }\end{array}$ & $\begin{array}{l}\text { - The description of the } \\
\text { nature of the problem to be } \\
\text { solved } \\
\text { AND/OR } \\
\text { - The proposed solution is } \\
\text { missing. }\end{array}$ & $\begin{array}{l}\text { - The nature of the problem to } \\
\text { be solved AND the } \\
\text { proposed solution are } \\
\text { clearly expressed, } \\
\text { BUT } \\
\text { - Links between the two are } \\
\text { not explicit. }\end{array}$ & $\begin{array}{l}\text { Clearly describes the nature } \\
\text { of the problem to be solved, } \\
\text { the proposed solution, } \\
\text { AND } \\
\text { - Provides some textual } \\
\text { and/or graphical evidence } \\
\text { that supports the proposed } \\
\text { solution. }\end{array}$ & $\begin{array}{l}\text { - Clearly describes the nature } \\
\text { of the problem to be solved, } \\
\text { the proposed solution, } \\
\text { AND } \\
\text { - Uses text and graphics to } \\
\text { provide a persuasive } \\
\text { argument to adopt the } \\
\text { proposed solution. }\end{array}$ \\
\hline $\begin{array}{l}\text { Development } \\
\text { (EVIDENCE) } \\
\text { Why is the proposed } \\
\text { solution the 'best' } \\
\text { solution? }\end{array}$ & $\begin{array}{l}\text { - Document is missing one or } \\
\text { more of the following: } \\
\text { 1. Alternative solutions, } \\
\text { 2. Major specifications, } \\
\text { AND } \\
\text { 3. Information pertinent to } \\
\text { the plan. }\end{array}$ & $\begin{array}{l}\text { - Document identifies each of } \\
\text { the following: } \\
\text { 1. Alternative solutions, } \\
\text { 2. Major specifications, } \\
\text { AND } \\
\text { 3. Information pertinent to } \\
\text { the plan. }\end{array}$ & $\begin{array}{l}\text { - Document shows some links } \\
\text { among the following: } \\
\text { 1. Alternative solutions, } \\
\text { 2. Major specifications, } \\
\text { AND } \\
\text { 3. Information pertinent to } \\
\text { the plan. }\end{array}$ & $\begin{array}{l}\text { - Document provides } \\
\text { persuasive argument that } \\
\text { links the following: } \\
\text { 1. Alternative solutions, } \\
\text { 2. Major specifications, } \\
\text { AND } \\
\text { 3. Information pertinent to } \\
\text { the plan. }\end{array}$ \\
\hline
\end{tabular}


Table II. Written Communication Portion of Scoring Rubric Used to Score Final Reports from EPICS' Teams

\begin{tabular}{|c|c|c|c|c|}
\hline & $-0-$ & $\begin{array}{c}-1- \\
\text { Needs Improvement }\end{array}$ & $\begin{array}{c}-2- \\
\text { Adequate }\end{array}$ & $\begin{array}{l}-3- \\
\text { Meets Expectations for a first } \\
\text { Draft of a Professional Report }\end{array}$ \\
\hline $\begin{array}{l}\text { Focus } \\
\text { (ORGANIZATION) } \\
\text { Is the organization of the } \\
\text { document effective? }\end{array}$ & $\begin{array}{l}\text { There appears to be no } \\
\text { organization of the } \\
\text { document's contents. }\end{array}$ & $\begin{array}{l}\text { - Organization of document is } \\
\text { difficult to follow due to a } \\
\text { combination of the } \\
\text { following: } \\
\text { 1. Inadequate transitions } \\
\text { 2. Rambling format } \\
\text { 3. Insufficient or irrelevant } \\
\text { information } \\
\text { 4. Ambiguous graphics }\end{array}$ & $\begin{array}{l}\text { The document can be easily } \\
\text { followed. A combination of } \\
\text { the following are apparent } \\
\text { in the document: } \\
\text { 1. Basic transitions are } \\
\text { used, } \\
\text { 2. A Structured format is } \\
\text { used, } \\
\text { 3. Some supporting } \\
\text { graphics are provided. }\end{array}$ & $\begin{array}{l}\text { - The document can be easily } \\
\text { followed. A combination of } \\
\text { the following are apparent } \\
\text { in the document: } \\
\text { 1. Effective transitions are } \\
\text { used, } \\
\text { 2. A professional format is } \\
\text { used, } \\
\text { 3. The graphics are } \\
\text { descriptive and clearly } \\
\text { support the document's } \\
\text { purpose. }\end{array}$ \\
\hline $\begin{array}{l}\text { Coherence } \\
\text { (CLARITY) } \\
\text { Are the sentences that } \\
\text { comprise the document } \\
\text { clear and effective? }\end{array}$ & $\begin{array}{l}\text { - Sentences are difficult to } \\
\text { read and understand. }\end{array}$ & $\begin{array}{l}\text { - The document contains } \\
\text { numerous distractions in } \\
\text { that appear in the a } \\
\text { combination of the } \\
\text { following forms: } \\
\text { 1. Flow in thought } \\
\text { 2. Graphical presentations } \\
\text { 3. Grammar/ } \\
\text { mechanics }\end{array}$ & $\begin{array}{l}\text { - The document contains } \\
\text { minimal distractions that } \\
\text { appear in a combination of } \\
\text { the following forms: } \\
\text { 1. Flow in thought } \\
\text { 2. Graphical presentations } \\
\text { 3. Grammar/mechanics }\end{array}$ & $\begin{array}{l}\text { - The document is clear and } \\
\text { concise. }\end{array}$ \\
\hline
\end{tabular}


seniors in the near future. To interpret a group's score without knowledge of a team's academic level could lead to inaccurate and misleading conclusions. The rubric was designed to evaluate team performance on a progressive basis. Students are anticipated to perform at the two lower levels in all categories in their freshman year and progress to the top level by their senior year. An expected future use of this scoring rubric will be to track students' progress from the time that they enter CSM until the time that they graduate.

\section{Results}

In the academic year of 1998-1999, a random sample of final reports from two cohorts of sophomore EPICS classes were scored by three faculty members who had been trained in the use of the final report scoring rubric. The first cohort completed their sophomore EPICS course in the fall of 1998 and the second cohort completed their sophomore EPICS course in the spring of 1999. Fourteen reports or 50 percent of the projects were reviewed for the fall and 13 reports or 60 percent of the projects were reviewed for the spring. A major objective of this study was to determine whether the developed scoring rubric would provide information that could be used for the following purposes:

1. To measure the performance of students,

2. To identify factors that influence student performance, and

3. To recommend changes for curriculum improvement.

A total score for each report was determined by summing the resultant scores across the rubric categories. The maximum possible total score was 15 . In order to ensure reliability, three evaluators individually scored a random sample of five (5) reports. Out of the total score of 15, discrepancies among the evaluators ranged from 1 to 2 points with an average of 1.2 points. This suggests that the amount of error in a team's score that was attributable to the given evaluator ranged from $6 \%$ to $13 \%$ with an average error of $7 \%$. The evaluators then split up the remaining reports for review by a single evaluator.

The distribution of total scores indicated a difference between the performance of the spring and fall courses. Based on results presented in Figure 2, students who completed EPICS in the fall semester performed better than did the students who completed this same course the next spring. The average total score for the fall was 9.6 whereas the average total score for the spring was 7.4. Across both cohorts, the overall average total score was 8.6.

In order to determine whether the average score for the fall and spring cohorts were significantly different, a Student t-test was completed. The results of the t-test confirm that the difference was

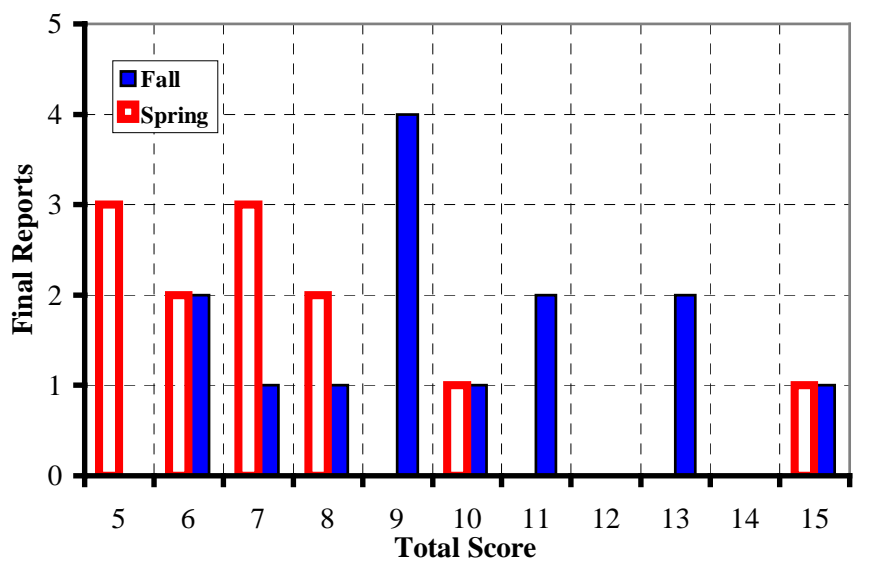

Figure 2: Number of Final Reports per Total Score Based on the Proposed Rubric. statistically significant for $\underline{\alpha}=.1 \quad(\underline{t}=2.10, \underline{\rho}=.05)$. 
Determination that the spring cohort performed at a lower level than did the fall cohort raised concerns that stimulated further analysis. Four factors had the potential of impacting upon these results: 1) Curriculum, 2) Students, 3) Mentors and 4) Projects.

Since the curriculum remained constant throughout the academic year, it was unlikely to have been an influencing factor. All sophomore students are required to complete the EPICS course in their sophomore year and the sophomore class is approximately equally distributed across the two terms. Students typically select the semester in which they will complete EPICS based on when this course best fits into their schedule. Since schedules very greatly among students, it is unlikely that the population of students who complete EPICS in the fall were academically different from the population of students who complete EPICS in the spring.

Faculty for the fall included 10 technical mentors and 3 communications mentors. Eight of the mentors had previous experience in the program. In the spring, faculty included 9 technical and 3 communications mentors. Seven of the spring mentors had previous experience. The similarity in the composition of these groups suggests that the composition of faculty was unlikely to have had an impact on results.

Another potential influencing factor is the nature of the projects that were completed during the semesters of interest. The fall semester consisted of 12 sections and 27 projects and the spring semester consisted of 11 sections and 19 projects. The projects for both semesters were solicited from industry, government and the local communities. These projects fell into the categories shown in Figure 1: Earth, Process, Product and Science and Economics. As suggested by Table III in the fall, $26.9 \%, 19.2 \%, 46.2 \%$, and $7.7 \%$ of the projects could be categorized as Earth, Process, Product and Science and Economics, respectively. The approximate distribution of students that will eventually complete degrees within each area is indicated in the middle column. A comparison of this estimate with the available fall projects indicates an almost ideal distribution of projects. In the spring, the bulk of the projects fell into the categories of Earth (47.6\%) and Product (42.9\%). Additionally, there were no projects available in Science and Economics. Although approximately $10 \%$ of the students will eventually major in Science and Economics, in the spring semester there were no Science and Economics projects from which to select. In other words, the spring semester students were limited by what projects were available and had very little opportunity to select a project that was of interest to them.

\begin{tabular}{|c|c|c|c|}
\hline \multicolumn{4}{|c|}{ Distribution of Project for EPIC $\frac{\text { Table III }}{251 \text { durin }}$} \\
\hline & Fall & Students & Spring \\
\hline Earth & 7 projects $(26.9 \%)$ & $17.2 \%$ & 10 projects $(47.6 \%)$ \\
\hline Process & 5 projects $(19.2 \%)$ & $25.2 \%$ & 2 projects $(9.5 \%)$ \\
\hline Product & 12 projects $(46.2 \%)$ & $38.1 \%$ & 9 projects $(42.9 \%)$ \\
\hline Science and Economics & 2 projects $(7.7 \%)$ & $10.3 \%$ & 0 projects $(0.0 \%)$ \\
\hline
\end{tabular}

Changes necessary to improve the curriculum rely on the results of the assessment method. With respect to the selection of an assessment method, Prus and Johnson ${ }^{19}$ suggest that "one overall truism applies: good method choices produce results useful for program enhancement and poor method choices are detrimental to the process." They also suggest that benefits to the program 
be measured in terms of direction (relevance), accuracy, and utility (functions that evaluate and improve). Benefits to the EPICS program are characterized in this study as the method's ability to identify both the successes and the improvements that need to be made to the EPICS program. Through the use of a scoring rubric we identified the availability of appropriate projects as a factor that may impact students' performances in sophomore EPICS. Knowledge of this factor has stimulated program improvements to be implemented into the curriculum this year.

\section{Conclusions}

Knecht ${ }^{17}$ has argued that improving curriculum is a problem solving exercise and, therefore, is subject to analysis from an engineering point of view. No matter what processes are assessed, whether they are chemical facilities or engineering design courses, two major parameters determine performance: 1) input/output characteristics and 2) factors within the process. This conceptualization of the assessment process has received further support by Angelo ${ }^{18}$ who has argued that it is processes as well as inputs and outputs that serve as a basis for an effective assessment of academic programs. The ideas of these two scholars are put into action in this study through the use of a scoring rubric.

The rubric proposed here provides a standardized method for evaluating the quality of teams' products based on the course learning outcomes. An original expectation of this research was that sophomore students would perform at approximately a "2" level across the rubric categories. This would result in a total score of 10 . On average, the students in this study had a total score of 8.6, slightly lower than anticipated. However, we believe that the use of the scoring rubric provided a valuable tool for both measuring student performance and stimulating curriculum improvement.

As a result of using the proposed scoring rubric, we found that students who completed the sophomore EPICS course in the spring were performing at a lower level than were their peers who completed the EPICS course in the fall. This stimulated further investigation and the determination that availability of appropriate projects had an impact upon team performances. In reaction, corrective measures are now underway to improve the educational experiences of future EPICS students.

\section{Future Research}

Currently, each department and program at CSM is in the process of developing and implementing an assessment plan (for more information on the CSM Assessment System, see $\mathrm{Moskal}^{20}$ ). One challenge that CSM continues to face is the demonstration that students' knowledge changes from the time that they enter CSM until the time that they graduate from CSM. A typical approach to measuring the impact of a program upon student learning is to collect baseline data (i.e., information concerning the students knowledge base) when students enter college and compare this information to data collected when students complete their degrees. A future goal of this research is to collect the baseline data in freshman EPICS and, using the proposed scoring rubric, track students' progress throughout the design stem. In other words, we anticipate using this rubric as a methodology for tracking student progress until the completion of their degrees. 
Bibliography

1. Accreditation Board of Engineering and Technology, "Engineering Criteria, 2000", $3^{\text {rd }}$ Edition, http://www.abet.org/EAC/eac2000.html, (visited Nov. 1999).

2. Kane, M., Crooks, T. \& Cohen, A., "Validating Measures of Performance,"Educational Measurement: Issues and Practice, vol. 18, no. 2, , pp. 5-17 (1999).

3. Philips, W., "A Look at the Criteria, "How do we measure success? Washington, DC: Association of Engineering Education, (1998).

4. Dixon, J.R., "New Goals for Engineering Education," Mechanical Engineering, vol. 113, pp. 56-62, (March 1991).

5. Maul, G.P., "Reforming Engineering Education," Industrial Engineering, vol. 26, no. 12, pp. 53-55, 67,(1994).

6. Masi, C.G., "Re-engineering Engineering Education," IEEE Spectrum, vol. 32, no. 9, p. 44 (1995).

7. Sheppard, S. \& Jeninson, R., "Freshman Engineering Design Experiences and Organizational Framework," International Journal of Engineering Education, vol. 13, no. 3, pp. 190-197, (1997).

8. Al-Holou, Bilgutay, N. M, Corletor, C., Demel, J.T., Fleder, R., Frair, K., Froyd, J.E., Hoit, M., Morgan, J. \&

Wells, D. L., "First-Year Integrated Curricula: Design Alternatives and Examples," Journal of Engineering

Education, vol. 88, no. 4, pp. 435-448, (1999).

9. King, R.H., Parker, T.E., Grover, T.P., Gosink, J.P. \& Middleton, N.T., "A Multidisciplinary Engineering

Laboratory Course," Journal of Engineering Education, vol. 88, no. 3, pp. 311- 316, (1999).

10. Douglas, J.M., Conceptual Design of Chemical Processes, McGraw-Hill Book Company, New York, New York, (1988).

11. Pahl, G. and Beitz, W., Engineering Design A Systematic Approach, Second Edition, Springer, London, England, (1996).

12. Horenstein, M., Engineering Design A Day in the Life of Four Engineers, Prentice Hall, Upper Saddle River, New Jersey, (1998).

13. Ullman, D.G., The Mechanical Design Process, The McGraw-Hill Companies, Inc. New York, New York. (1997).

14. Bieniawski, Z.T., "Towards a creative design process in mining", Mining Engineering, p. 1040, (November, 1998).

15. Brookhart, S. The Art and Science of Classroom Assessment: The Missing Part of Pedagogy. ASHE-ERIC

Higher Education Report (Vol. 27, No.1). Washington, DC: The George Washington University, Graduate School of Education and Human Development, (1999).

16. Leydens, J. and Thompson, D., Writing Rubrics Design (EPICS) I, Internal Communication, Design (EPICS) Program, Colorado School of Mines, (August, 1997).

17. Knecht, Robert, "An Engineering Approach to the Assessment of the First-Year Design Sequence at the Colorado School of Mines", ASEE Conference, Seattle Washington, June, (1998)

18. Angelo, T.A., "Doing Assessment As Though Learning Mattered Most", The 1998 ERM Distinguished

Lecture, ASEE Conference, Seattle Washington, June, (1998)

19. Prus, J. and Johnson, R., "A Critical Review of Student Assessment Options," Assessment and Testing: Myths and Realities, vol. 88, (Winter 1994)

20. Moskal, B. A University Assessment System: Establishing Consistency Across an Institution, Unpublished manuscript, (1999).

\section{ROBERT KNECHT}

Robert Knecht's 25 years of experience in the industry focused on technical and management support for minerals, energy and waste projects. In addition, he supervised management support for contracts which responded to DOE Cost and Schedule requirements. He directs an engineering design program based on a curriculum that incorporates projects from industry with commercially available, computer-aided design software. His projects require students to implement a design methodology in teams to resolve open-ended problems and to communicate both in written and verbal forms the results of their work.

\section{BARBARA MOSKAL}

Dr. Barbara Moskal, is Associate Director of the Center for Engineering Education. She was the evaluator and designer of measurement instruments for Competence and Confidence project to improve the middle grade teacher's knowledge of mathematics content and instructional pedagogy. Prior to joining CSM, she was a member of the 
assessment team for Quantitative Understanding: Amplifying Student Achievement and Reasoning (QUASAR). QUASAR is a national project to improve instruction for students located in disadvantaged communities. Dr. Moskal is trained in both quantitative and qualitative methodologies.

\section{MICHAEL PAVELICH}

Dr. Pavelich, a Professor of Chemistry at CSM, has been working in curriculum development and assessment for over twenty years. He was one of the originators of the CSM EPICS Program and served as its Director from 19841988 when it went from a pilot program to a mandate for all CSM students. Dr. Pavelich pioneered the use of the Perry Intellectual Development Model measurements in the assessment of design programs and is currently ending work on a FIPSE project to do these measurements using interactive computer software with neural net analysis. He founded the CSM Office of Teaching Effectiveness and has given several workshops to engineering faculty around the country on curriculum development, teaching through student teams and assessment. 